\title{
Stock status of coconut crab (Birgus latro) in Daeo, Morotai Island District, North Maluku, Indonesia
}

\author{
RUGAYA H. SEROSERO ${ }^{1, \boldsymbol{}}$, SULISTIONO ${ }^{2}$, NURLISA A. BUTET ${ }^{2}$, ETTY RIANI ${ }^{2}$ \\ ${ }^{1}$ Program of Aquatic Resources Management, Faculty of Fisheries and Marine Science, Universitas Khairun. J1. Pertamina Kampus II Unkhair, Ternate \\ 97719, North Maluku, Indonesia. Tel./fax.: +62-921-3110907, ^email: rugayaserosero@ gmail.com \\ ${ }^{2}$ Department of Aquatic Resources Management, Faculty of Fisheries and Marine Sciences, Institut Pertanian Bogor. Jl. Agatis, Babakan, Dramaga, \\ Bogor 16680, West Java, Indonesia
}

Manuscript received: 23 December 2020. Revision accepted: 9 January 2021.

\begin{abstract}
Serosero RH, Sulistiono, Butet NA, Riani E. 2021. Stock status of coconut crab (Birgus latro) in Daeo, Morotai Island District, North Maluku, Indonesia. Biodiversitas 22: 624-632. The populations of coconut crabs (Birgus latro) in nature continue to decline due to their simple capture for human consumption. This study aimed to determine the status of coconut crab stock in Daeo, Morotai Island Regency, North Maluku, Indonesia including estimations of growth parameters and population size. This research was conducted from October 2016 to September 2017. Growth parameters were estimated based on 12 monthly length-frequency samples. Data analysis was carried out using the ELEFAN I method on the FiSAT II program for estimating growth parameters, and the Schnabel method for estimating population size. The results showed that the level of exploitation of male and female coconut crabs in Daeo was high (E > 0.5). The asymptotic length L $\infty$ for males was $56.96 \mathrm{~mm}$ thoracic length (TL) and that of females $52.50 \mathrm{~mm}$ TL. The growth coefficient K for males was 0.14 and that for females 0.16 . Length to is -1.026 (male) and -0.913 (female). The results generated using the Schnabel method suggested that the population size of the coconut crab in Daeo was 7,466 to 73,948 individuals considering a confidence interval of $95 \%$. The recapture of tagged coconut crabs was merely $0.82 \%$.
\end{abstract}

Keywords: Birgus latro, Coconut crab, Daeo, Morotai island, stock status

\section{INTRODUCTION}

Coconut crabs, (Birgus latro) have limited distribution and dispersal only occurs during the marine larval phase in their life cycle. During the terrestrial adult phase, the ocean is a dispersal barrier. The stock size of coconut crab in the area is determined by factors related to reproductive success, the ability of larvae, post-larvae (glaucothoes), and juveniles to survive to adulthood, environmental conditions, and the extent of exploitation by humans.

Capturing coconut crabs for human consumption is comparatively simple to harvesting activities that have been continuing, resulting in high levels of exploitation and population declines especially in areas with high levels of human activities. The populations of coconut crabs on tropical islands both in the Pacific Ocean and the Indian Ocean are currently decreasing (Krieger et al. 2012). The high exploitation of coconut crabs by humans is due to the delicious taste of the meat and its high nutritional values. Coconut crabs are also believed to be aphrodisiacs (stimulants of sexual arousal), but this has not been clinically tested (Fletcher et al. 1990).

There is a considerable lack of information on the condition of coconut crab stocks in areas where coconut crabs potentially occur. Buden (2012) stated that no quantitative assessments on the status of coconut crab populations on more than 600 islands up the Federated States of Micronesia (FSM) have been published yet. As stated by Drew et al. (2010), Christmas Island in the Indian Ocean harbors one of the largest populations of $B$. latro in the world, with estimates ranging up to 1257342 (Schiller 1988). For North Maluku, no studies exist so far which reveal the stock status of $B$. latro.

Estimates of the stock condition and the size and density of coconut crab populations can be used as a fundamental basis to determine management strategies for protecting and conserving these populations or sustainable use of coconut crabs as a potential marine resource for human consumption in the area, where fish is predominantly consumed compared to non-fish resources such as crustaceans and molluscs. Several methods of population size estimation, such as capture-recapture (Fletcher et al. 1990), and investigation of coconut crab migrational and non-migrational movements (Krieger et al. 2012) have been used by previous researchers. In this study, coconut crabs were tagged with differently colored nylon strings tied to the dactylus of the left and right walking leg. The aim of our study was, therefore, to reveal the stock condition of coconut crabs in Daeo Regency of Morotai Island, North Maluku, Indonesia including estimations of age group, growth rate, mortality, rate of exploitation and population size. 


\section{MATERIALS AND METHODS}

\section{Study site}

This research was conducted in Daeo, District of Morotai Island, North Maluku, Indonesia and carried out at three stations from October 2016 to September 2017.

\section{Data collection}

Estimation of age group and growth parameters

Sampling was done by using coconut meat bait that was divided into several parts and coconut meat that was mashed. The bait was placed in the morning until noon and the arrest at night starts at 21:00. Coconut crabs were captured by hand. Checking the catch is done every $2-3$ hours. The arrest ended at 06:00 eastern Indonesia time (WIT).

The catch of coconut crab samples weighed in total, measuring thorax length (TL) and length of cephalothorax with rostrum $(\mathrm{Cp}+\mathrm{r})$ according to the instructions of Fletcher et al. (1990).

\section{Estimation of population size}

The estimation of the population size of coconut crabs in Daeo was determined by Schnabel's multiple tagging method. Individual coconut crabs caught every month were marked with differently colored nylon strings on the left and right dactylus of the walking leg. In October, November, December, January, February, and March, coconut crabs were tagged with nylon strings on the dactylus of the left leg in the following color sequence: yellow, green, orange, black, pink and blue. In April, May, June, July, August, and September, crabs were tagged on the dactylus of the right road leg in the color-combination sequence: yellow and black, green and black, orange and black, pink and black color, blue and black, and orange and green. Coconut crabs that were recaptured every month were re-tagged with a string of the same color as before, either on the left or right leg according to the color that had been determined based on the month of catching.

Estimating population sizes using the Schnabel method (multiple census) is based on several assumptions: (i) individuals in the population have the same probability to be caught so that sampling is done randomly; (ii) there is no difference between tagged and untagged individuals regarding the probability of being captured or preyed on; (iii) tagged individuals must be randomly distributed when released; (iv) there is no significant increase in population size via birth and immigration of untagged individuals; (v) sampling must be random, and the time between sampling must be long enough to allow the intermixing of tagged with untagged individuals.

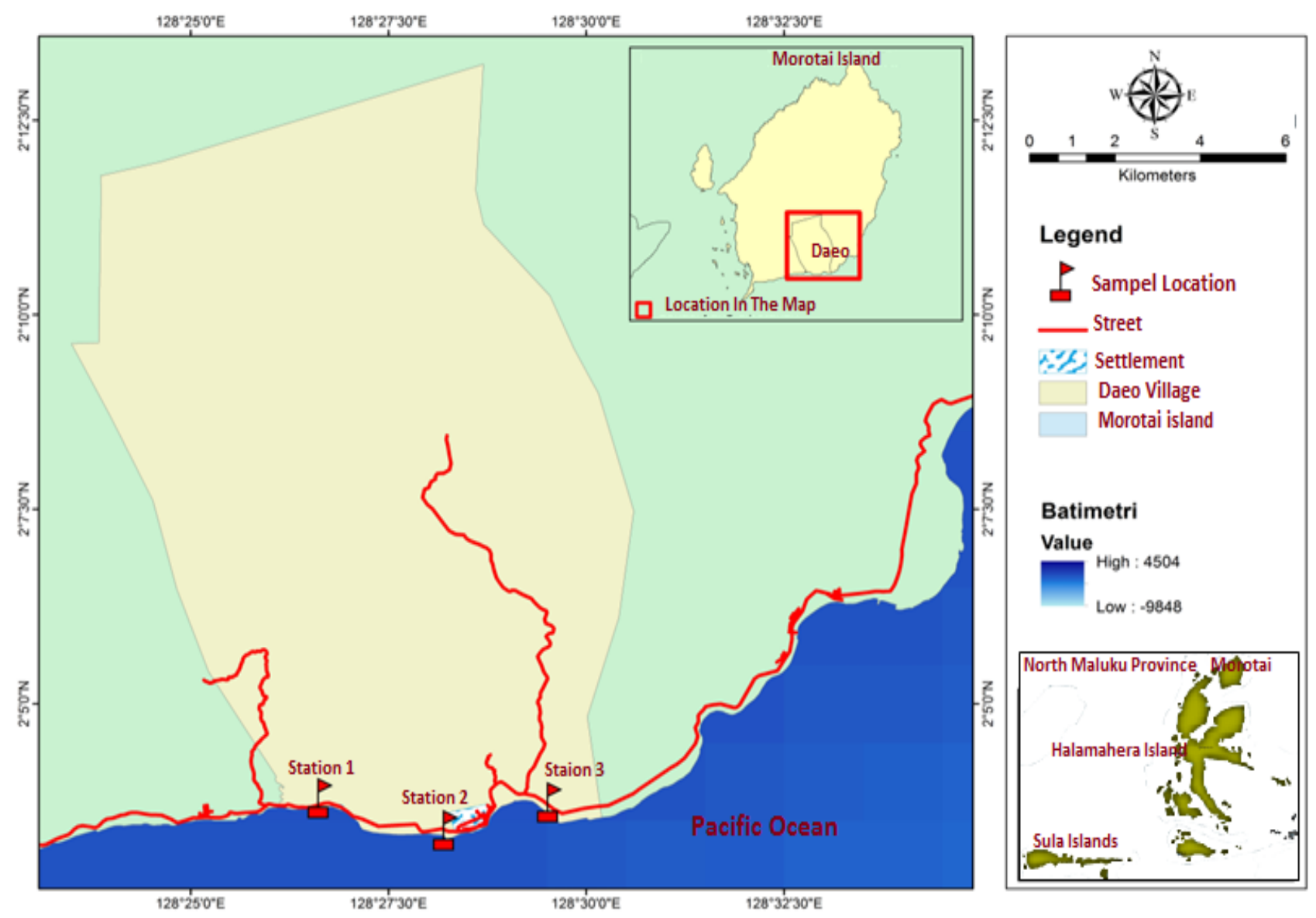

Figure 1. Location of sampling stations in Daeo, District of Morotai Island, North Maluku, Indonesia 
After tagging, coconut crabs were returned to the site of capture at the respective observation stations, and the total number of recaptured coconut crabs during this period was recorded. During the observation period, a total of 581 individuals were caught, consisting of 314 male and 267 female individuals. 216 individuals $(37 \%)$ of these 581 individuals were not tagged and released, but used to study their reproductive development. The remaining 365 individuals $(63 \%)$ were tagged and used in the capturerecapture study.

\section{Data analysis}

Estimation of age groups and growth parameters

Estimation of age groups was carried out by analyzing the frequency data for the values of TL for every month, using the Bhattacharya method in the FISAT II program.

\section{Growth parameters}

Growth parameters include growth rate $(\mathrm{K})$, theoretical maximum length $(\mathrm{L} \infty)$, and age at size $0 \mathrm{~mm}\left(\mathrm{t}_{0}\right)$. The estimation of these three parameters was approached by the ELEFAN I (Electronic Length Frequency Analysis) method in the FiSAT (Fish Stock Assessment Tools) II program.

The growth rate of coconut crabs was estimated using the von Bertalanffy growth equation (Sparre and Vanema 1999).

$$
\mathrm{L}_{\mathrm{t}}=\mathrm{L}_{\infty}\left[1-\mathrm{e}^{-\mathrm{K}(\mathrm{t}-\mathrm{to})}\right]
$$

Where, $\mathrm{L}_{\mathrm{t}}$ is the predicted length TL at age $\mathrm{t}(\mathrm{mm}), \mathrm{L} \infty$ is the maximum length or asymptotic length $(\mathrm{mm}), \mathrm{K}$ is the growth coefficient (month-1), and $\mathrm{t}_{0}$ is the hypothetical age at zero length (month).

Parameters of the value $t_{0}$ (theoretical age) were estimated by Pauly's (1984) empirical formula:

$$
\log \left(-\mathrm{t}_{0}\right)=-0.3922-0.2752 * \log \mathrm{L} \infty-1.0380 * \log \mathrm{K}
$$

\section{Mortality and exploitation rate}

Natural mortality (M) was estimated by Pauly's (1984) empirical formula using the FiSAT program:

$$
\begin{aligned}
& \operatorname{LnM}=-0.0152-0.279 * \mathrm{LnL}_{\infty}+0.6543 * \mathrm{LnK}+0.463 \\
& * \operatorname{LnT}
\end{aligned}
$$

Where, $\mathrm{M}$ is the natural mortality, $\mathrm{L} \infty$ is the asymptotic length in the von Bertalanffy growth equation, $\mathrm{K}$ is the growth coefficient in the von Bertalanffy growth equation, $\mathrm{T}$ is the average environmental temperature $\left({ }^{\circ} \mathrm{C}\right)$ of the coconut crab habitat.

The fishing mortality $(\mathrm{F})$ (for coconut crabs catching mortality) was determined by $\mathrm{F}=\mathrm{Z}-\mathrm{M}$.

The rate of exploitation (E) was determined by comparing fishing mortality (F) to total mortality (Z) (Pauly 1984):

$$
\mathrm{E}=\mathrm{F} /(\mathrm{F}+\mathrm{M})=\mathrm{F} / \mathrm{Z}
$$

Fishing mortality (F) or the optimum rate of exploitation according to Gulland (1971) in Pauly (1984) was: $\mathrm{F}_{\text {optimum }}=\mathrm{M}$ and $\mathrm{E}_{\text {optimum }}=0.5$.

\section{Estimation of population size}

Estimation of population size using the tagging method according to Schnabel, namely multiple censuses as follows (Krebs 1989).

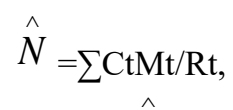

Where, $\hat{N}$ is the estimation of population size, Mt is the number of samples marked at time $\mathrm{t}, \mathrm{Ct}$ is the number of samples captured at time $\mathrm{t}$, Rt is the number of samples marked and re-caught in the sample Ct.y

The confidence interval used was $95 \%$. According to the Schnabel method, the confidence interval for the population estimation is based on a Poisson distribution, if the number of recaptured animals is less than 50 , if the number of recaptured animals is greater than 50, it is based on a normal distribution.

Variance $=\sum \mathrm{Rt} / \sum(\mathrm{CtMt})^{2}$
Standard error $(\mathrm{se})=\sqrt{ } \sum \mathrm{Rt} /\left(\sum \mathrm{CtMt}\right)^{2}$

\section{RESULTS AND DISCUSSION}

\section{Estimation of age group and growth parameters Coconut crab size distribution}

The size distribution of coconut crabs during one year of observation is shown in Figures 2 and 3. Coconut crabs caught in Daeo were dominated by a TL of about 30-40 $\mathrm{mm}$, both in males and females. No coconut crabs smaller than $10 \mathrm{~mm}$ TL were found.

\section{Separation of age groups}

Based on the average values for TL of male and female coconut crabs, the population of male coconut crabs mostly consisted of one age group, except for November 2016, December 2016 and March 2017, where two age groups were found (Figure 4). The population of female coconut crabs consisted of one age group during the whole observation period (Figure 5). Different age groups correspond to different generations.

\section{Estimation of growth parameters}

The results for the estimations of growth parameters asymptotic length $(\mathrm{L} \infty)$, growth coefficient $(\mathrm{K})$, age at length $0 \mathrm{~mm}\left(\mathrm{t}_{0}\right)$ and lifespan, as generated using ELEFAN 1 , are summarized in Table 1 .

Estimations for L $\infty$ were higher in males than females. Estimations for $\mathrm{K}$, however, were higher in female than male coconut crabs. The lifespan of males was much higher than that of females. With the estimations of the growth parameters obtained using ELEFAN 1, von Bertalanffy growth equations were generated (Figure 6). 


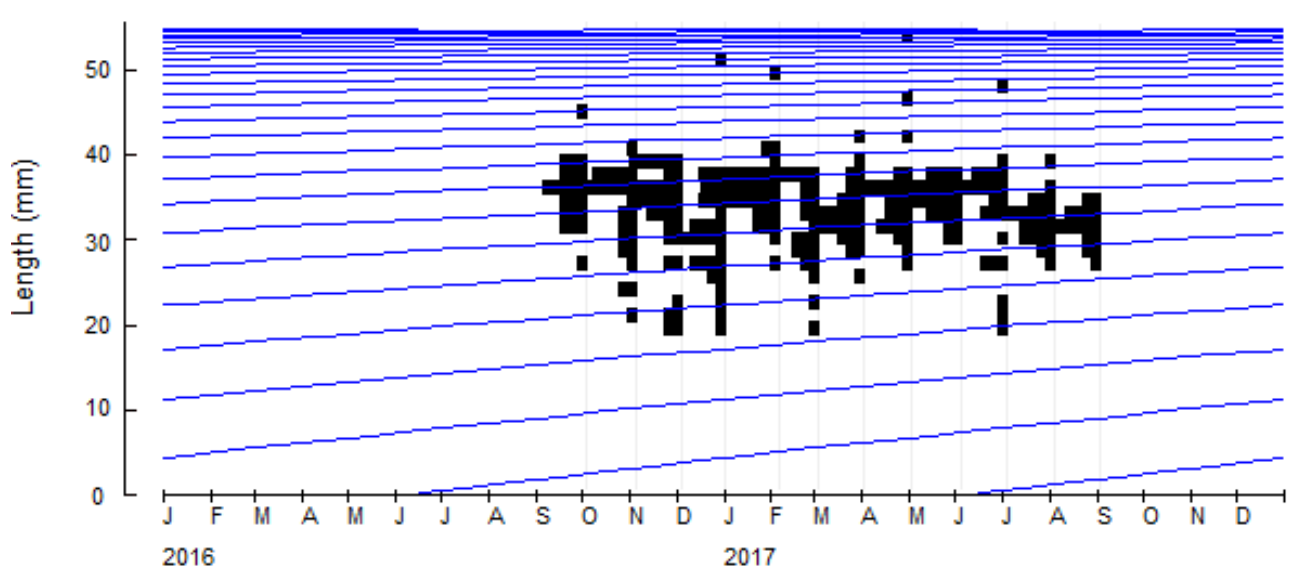

Figure 2. Distribution of the length (as TL) of male coconut crabs at Daeo using the von Bertalanffy plot (October 2016-September 2017)

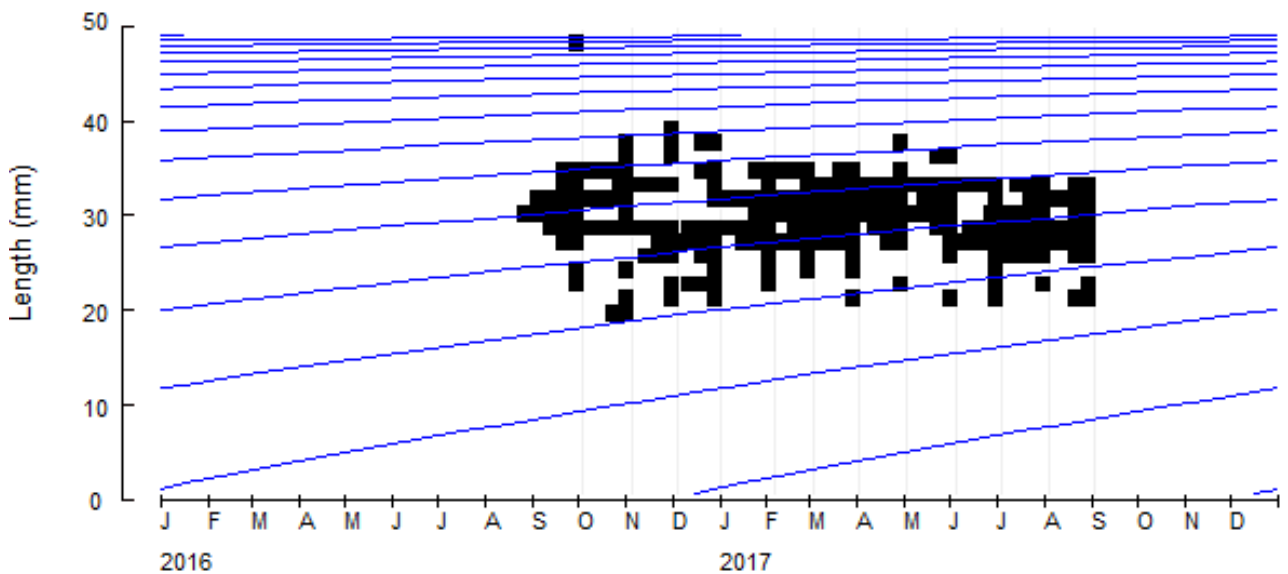

Figure 3. Distribution of the length (as TL) of female coconut crabs at Daeo using the von Bertalanffy plot (October 2016-September 2017)

\section{Mortality and exploitation rate}

Based on the results analysis total mortality $(\mathrm{Z})$, natural mortality (M), catch mortality (F) and the rate of exploitation $\mathrm{E}$ (Table 2), it was indicated that male and female coconut crabs in Daeo have been were overfished.

\section{Estimation of population size Capture-recapture study}

The success of the capture-recapture study was very poor. Of the 365 coconut crab individuals that were tagged, only three individuals were recaptured $(0.82 \%)$, namely one female coconut crab captured and tagged at Station I in February 2017 and recaptured at Station I in April 2017, one male coconut crab captured and tagged at Station II in November 2016 and recaptured at Station II in April, and one male captured and tagged at Station II in December 2016 and recaptured in March 2017 at Station II.

Based on the number of captures and recaptures in the period from October 2016 to September 2017, the estimation for the population size of coconut crabs in Daeo, Morotai Island, was 20,163 individuals with a variance of $8.1989 \times 10^{-10}$ and a standard error of $2.8634 \times 10^{-5}$. The lower limit of the confidence interval at the $95 \%$ confidence level was 0.818 and the upper limit was 8.102. Thus, the confidence interval with a confidence level of
$95 \%$ of the population of coconut crabs was in the range of 7466 to 73948 individuals.

\section{Discussion}

Estimation of age group and growth parameters

In the present study, no coconut crabs with a thorax length (TL) of less than $10 \mathrm{~mm}$, and only a few individuals with a TL less than $20 \mathrm{~mm}$ were found. This was most likely caused by human fishing activities or by placing bait in habitats that are normally occupied by adult coconut crabs; juvenile coconut crabs tend to occupy habitats near the coast. Brown and Fielder (1991) state that adult coconut crabs usually occupy rock crevices, hide in holes in logs and trees or dig in the substrate, and they often have their hiding places on vegetated land up to three kilometers away from the sea.

Even though most commonly used in tropical fish stock assessment, growth parameters and age in crustaceans, such as the coconut crab, can be estimated based on length groups, with e.g. thorax length as the applied body length parameter (Sparre and Venema 1999). Of the coconut crabs sampled in this study, both males and females predominantly belonged to a single age group. This underlying low variation in length was probably caused by the slow growth of coconut crabs. 
The fact that the values for the asymptotic length $(\mathrm{L} \infty)$ of males were larger than those of females and that the values for the growth coefficient $(\mathrm{K})$ of females were larger than those of males suggests, that males grow larger than females, but female coconut crabs reach $L \infty$ faster than male coconut crabs. In the northern part of Vanuatu, Fletcher et al. (1991) found a coconut crab with a larger $\mathrm{L}_{\infty}$ $\left(\mathrm{L}_{\infty}=80.00 \mathrm{~mm}\right)$ than in this study, where $\mathrm{L} \infty$ of males was $68.96 \mathrm{~mm}$. On Hatoma Island, Sato and Yoseda (2013) found $\mathrm{L} \infty$ values of $69.87 \mathrm{~mm}$ for males and $42.79 \mathrm{~mm}$ for females, thus, similar to the results of this study, male L $\infty$ was higher than female $L \infty$, but the difference in $L \infty$ values was much more pronounced. Regarding values for K, Sato and Yoseda (2013) also had lower values for males $(\mathrm{K}=$ $0.061)$ than for females $(K=0.091)$, which again suggests that females reach $L \infty$ faster than males. In contrast, Supyan et al. (2015) estimated $\mathrm{L}_{\infty}$ and $\mathrm{K}$ values based on the length parameter $\mathrm{Cp}+\mathrm{r}$ and maintenance data of three months in Lebak Banten with $\mathrm{L} \infty=192.4 \mathrm{~mm}$ for males and $\mathrm{L} \infty=151.9 \mathrm{~mm}$ for females, and with $\mathrm{K}=1.127$ for males and $\mathrm{L} \infty=1.063$ for females.
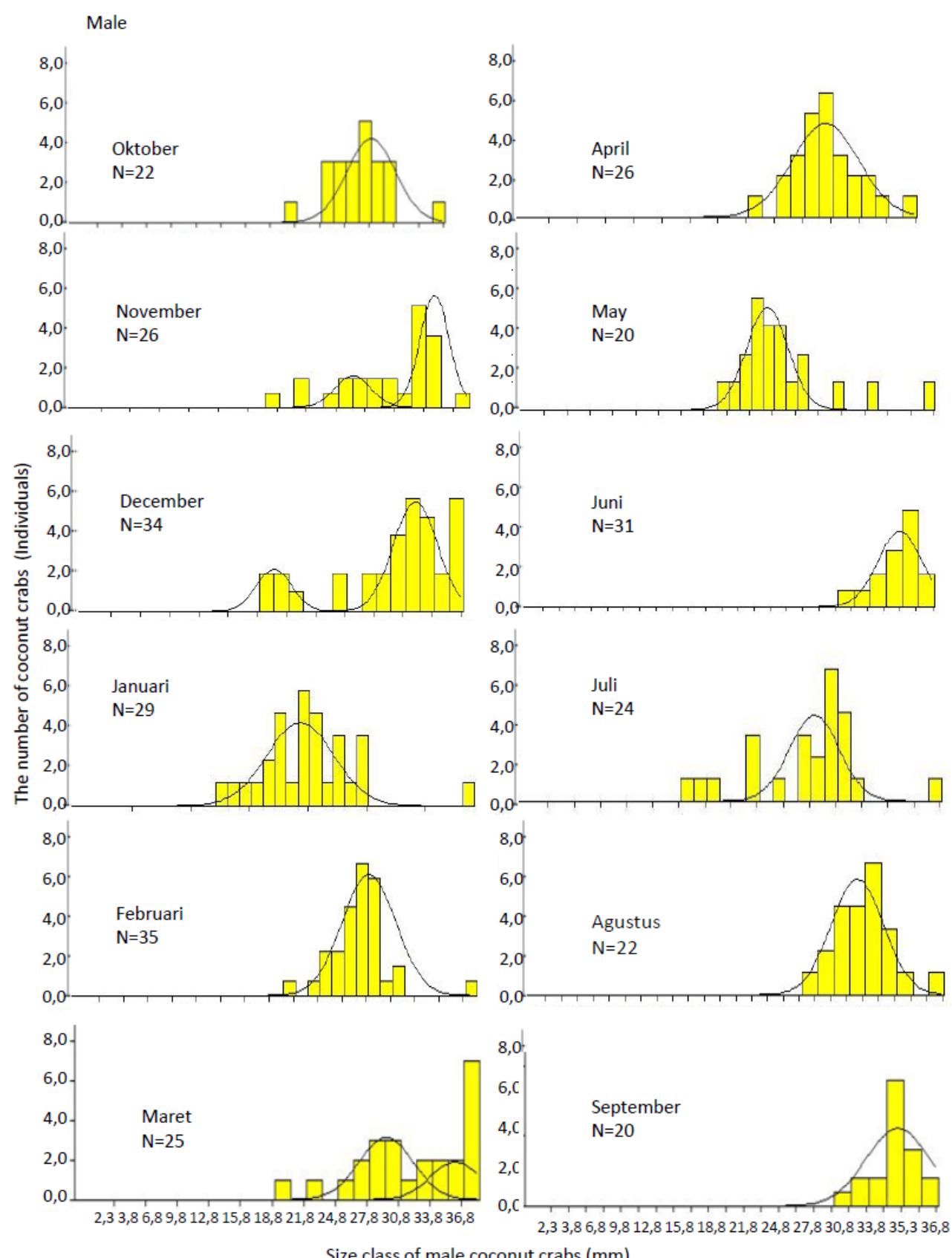

Figure 4. Frequency distribution of the thorax length of male coconut crabs in Daeo during the observation period from October 2016September 2017, using the Bhattacharya analysis 
Female
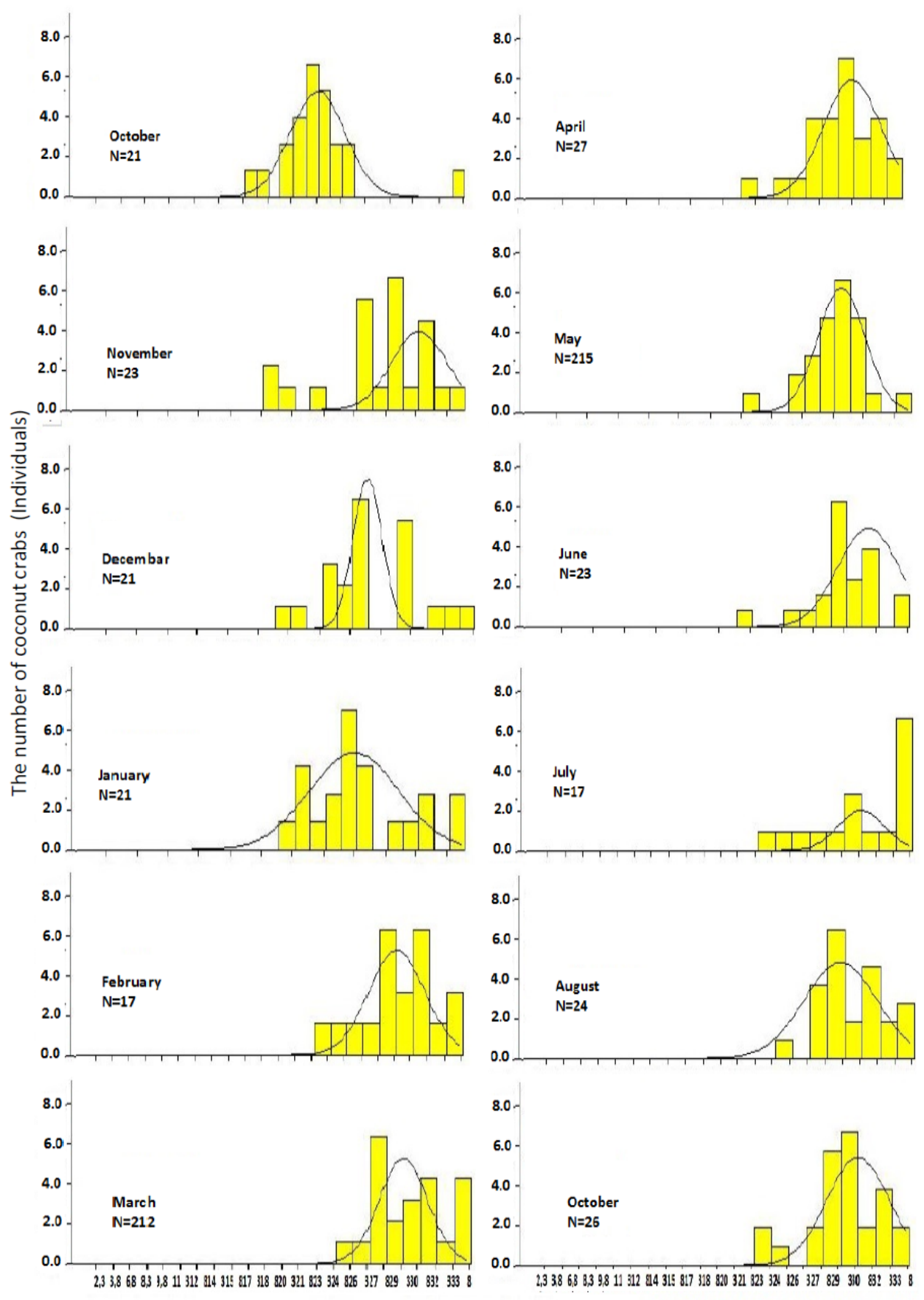

Size class of female coconut crabs $(\mathrm{mm})$

Figure 5. Frequency distribution of the thorax length of female coconut crabs in Daeo during the observation period from October 2016September 2017, using the Bhattacharya analysis

Table 1. The growth parameters and lifespan coconut crabs in Daeo Morotai Island District, North Maluku, Indonesia

\begin{tabular}{llccc}
\hline \multicolumn{1}{c}{ Sex } & L $\infty(\mathbf{m m})$ & K (per year) & To (year) & Lifespan (year) \\
\hline Male & $56.96 \mathrm{~mm}$ & 0.14 & -1.026 & 20.40 \\
Female & $52.50 \mathrm{~mm}$ & 0.16 & -0.913 & 17.80 \\
\hline
\end{tabular}



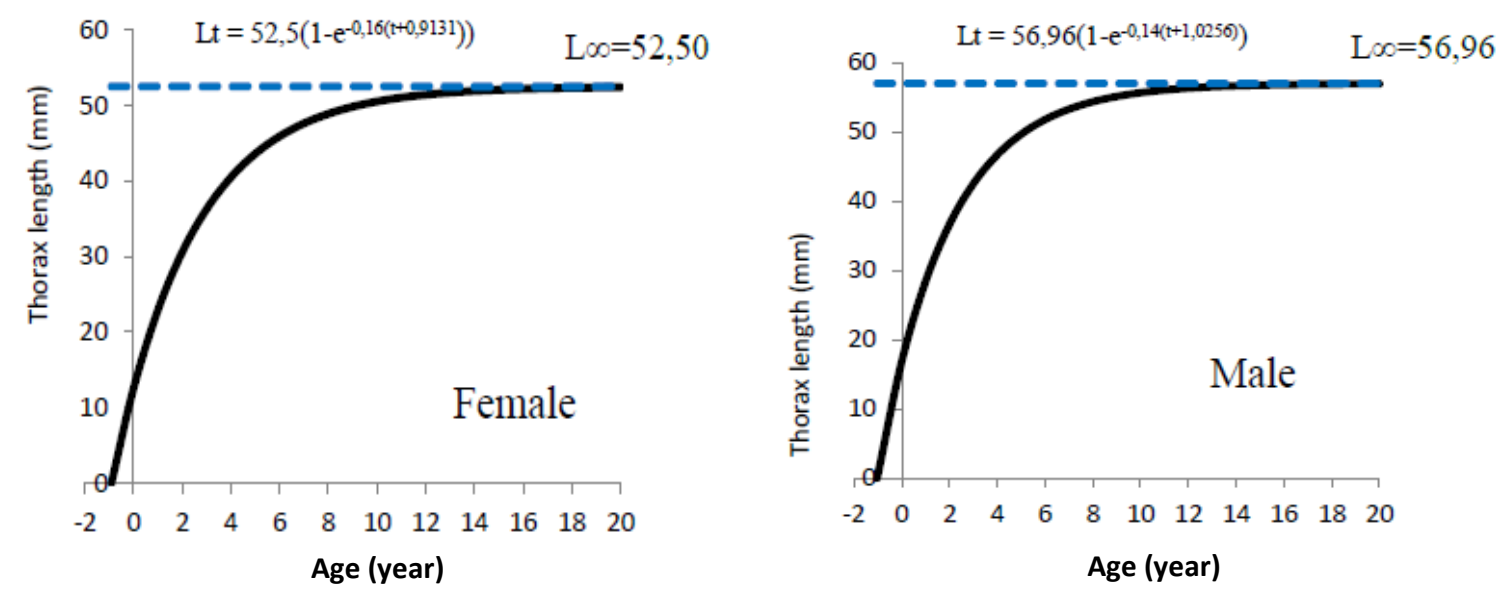

Figure 6. Von Bertalanffy growth curves for male and female coconut crabs sampled in Daeo, based on values for the thorax length of male and female coconut crabs, respectively

Table 2. Total mortality (Z), natural mortality (M), fishing mortality (F), and rate of exploitation (E) of male and female coconut crabs in Daeo Morotai Island District, North Maluku, Indonesia

\begin{tabular}{lcccc}
\hline \multicolumn{1}{c}{ Sex } & $\mathbf{Z}($ year) & M (per year) & F (year) & $\mathbf{E}$ \\
\hline Male & 1.25 & 0.42 & 0.83 & 0.67 \\
Female & 1.17 & 0.47 & 0.70 & 0.60 \\
\hline
\end{tabular}

Thus, even though females again had smaller L $\infty$ values than males, they also had smaller $\mathrm{K}$ values than males, suggesting slower growth. Slower growth of female coconut crabs and smaller $\mathrm{L}_{\infty}$ values might be caused by the high energy requirements of female crabs during reproduction because females produce a large number of eggs each year (Sato et al. 2008). During reproductive activity, female crabs also spend more time in coastal areas where there often can be a lack of food.

A low $\mathrm{K}$ value indicates the ability to achieve a larger L $\infty$ value so that the age is greater, and vice versa (Sparre and Venema 1999). The growth of an animal is very dependent on food supply, and variation in food supply can cause variations in growth characteristics (Nikolsky 1963). Growth parameters play an important role in the assessment of stocks. Coconut crabs are the largest land crustaceans and can reach a bodyweight of up to $4 \mathrm{~kg}$ and live up to 60 years (Brown and Fielder 1991; Grenaway 2003; Krieger et al. 2012). Based on the estimation of life expectancy or lifespan in this study, coconut crabs in Daeo had the age of 21.39 years (males) and of 11.24 years (females). Sato and Yoseda (2013) reported that female coconut crabs have a shorter life span than male coconut crabs, but until now there have been no reports revealing the longevity of $B$. latro.

Mortality in coconut crabs can be caused by human capture for consumption, which would then be assigned as fishing mortality (F). Natural mortality (M) of crabs may include death due to predation, disease, and age (Sparre and Venema 1999). The value of $M$ is related to the growth values of the von Bertalanffy equation, namely $\mathrm{K}$ and $\mathrm{L}_{\infty}$. According to Pauly (1984), environmental factors that greatly influence the value of $\mathrm{M}$ are the average ambient temperature of the habitat, the maximum mean length $\mathrm{L}_{\infty}$ and growth rate K. M of male (0.419) and female (0.468) coconut crabs during the observation period was lower than F of male (0.831) and female crabs (0.703). The high value of $\mathrm{F}$ and the decline $\mathrm{M}$ indicate that overfishing conditions have occurred. According to Widodo and Suadi (2006), the high rate of fishing mortality $(\mathrm{F})$ indicates the occurrence of growth overfishing. This can also be seen from the comparison of $\mathrm{Lc}$ and $\mathrm{Lm}$ values which show that the average size of caught coconut crab is smaller than the size of the first time gonads ripen. The rate of exploitation has also exceeded the optimum exploitation limit by $50 \%$ (Gulland 1971 in Pauly 1984). This means that the coconut crab in Daeo has experienced more biological capture. Biological overfishing can be classified into growth overfishing and recruitment overfishing.

The E values of male coconut crabs of 0.665 and female crabs of 0.600 suggest, that the level of exploitation of coconut crab stock in Daeo is high and that the stock has been overexploited, which is the case because $\mathrm{E}>0.50$. The condition of coconut crab resource utilization has experienced overfishing biologically (E> 50\%) (Gulland 1983). This high utilization rate must be accompanied by appropriate management actions. Some management actions that can be taken are limiting the size of coconut crabs that can be caught and limiting fishing during the highest spawning season.

\section{Estimation of population size}

Estimation of the population size of coconut crabs using the Schnabel method is an attempt to preserve the sustainability of coconut crab resources in their natural habitat. Utilizing resources but still maintaining the sustainability of these resources by returning catches to the population. Krebs (1989) states that one of the important assumptions of the Schnabel method is, that tagged and untagged animals have the same probability to be caught. 
Recapture of tagged coconut crabs was very low (0. 82\%). We believe that this pattern is associated with the behavior of coconut crabs which tend to hide in their refuges. Schiller et al. (1991) tagged 900 female individuals of $B$. latro in Vanuatu, but recaptured only around 2\% (17 individuals); on Christmas Island, they marked 1700 female crabs and could only recapture 9\% (150 individuals) Schiller et al. (1991) reported that large islands had a low recapture rate $(0.1 \%)$, whereas on smaller islands (less than 2 ha) recapture could reach $20 \%$. Sato et al. (2013) estimated the growth of $B$. latro by using passive integrated transponder tags (PIT) as a tagging method, but here, recapture was also comparatively poor, because only $15 \%$ of tagged coconut crabs were recaptured. Oka et al. (2015) used carapace indentation patterns in order to recognize individual crabs, and of 485 crabs that they photographed, $26 \%$ were reencountered.

Coconut crabs often hide in their habitat during the day and are active at night (nocturnal). However, in nonpopulated areas, diurnal coconut crabs can be found, whereas coconut crabs in populated areas are often nocturnal (Fletcher et al. 1991). Coconut crabs tend to stay in the same place, in their home range. They often stay in burrows throughout the day, and when replaced from their home range, they show excellent homing instincts (Fletcher et al. 1990; Krieger et al. 2012). In Okinawa, Japan, Oka et al. (2016a) found male and female coconut crabs that made movements of less than 200 meters. The same was also found by Krieger et al. (2012) on Christmas Island. Oka et al. (2016b), also found that there was no correlation between the release period and the moving distance of male and female coconut crabs $\left(\mathrm{R}^{2}<0.08\right)$ and there was no correlation between the size and moving distance of recaptured coconut crabs before winter $\left(\mathrm{R}^{2}<0.06\right)$.

The estimation of the population size of coconut crabs in Daeo, Morotai Island, was comparatively high, with 20163 individuals, ranging from 7466 individuals to 73948 individuals (95\% confidence interval). However, a high level of exploitation $(E>0.5)$ for human consumption as well as intensive human activities such as fishing, agriculture and human settlement probably reduced the population of coconut crabs. Sulistiono et al. (2013) estimated the stock of small coconut crabs (crablets) in Yoi Island in Central Halmahera, which ranged from 24-36 individuals / $100 \mathrm{~m}^{2}$ with an average of 28 individuals / $100 \mathrm{~m}^{2}$ (per station) or 31 individuals $/ 100 \mathrm{~m}^{2}$ (all stations). Assuming that half of the area (2929.074 ha) was coconut crab habitat (1464 ha), the stock of these crabs were estimated at 3513.600-5270.400 (per station) or 4522.133 (all stations) in the area of about 1462 ha was 3513.6005270.400 (per station) or 4522.133 (all stations).

In conclusion, the level of exploitation of coconut crab stock in Daeo has been overtaken (overexploitation) with an $\mathrm{E}$ value $>0.50$. The natural mortality of male and female coconut crabs was lower than the fishing mortality. The increase in fishing mortality and the decrease in natural mortality indicates that overfishing conditions have occurred. The growth coefficient of male coconut crabs was 0.14 per year and that of females was 0.16 per year, suggesting, that female coconut crabs reach $\mathrm{L} \infty$ faster than male coconut crabs, but the speed of their growth to achieve $L_{\infty}$ values tends to be similar. The capturerecapture study carried out over a period of one year using nylon strings as tags provided very poor recapture results of only $0.82 \%$ ( 3 out of 365 samples). The low recapture was assumedly caused by the crabs' tendency to hide for a long time in their habitat.

\section{ACKNOWLEDGEMENTS}

We thank to coconut crab catchers for their kind support and assistance during data collection.

\section{REFERENCES}

Brown IW, Fielder DR. 1991. The Coconut Crab: Aspects of the Biology and Ecology of Birgus latro in the Republic of Vanuatu. Australian Centre for International Agricultural Research, Canberra, Australia.

Buden DW. 2012. Coconut crabs, Birgus latro (Anomura: Coenobitidae), of Sorol Atoll, Yap, with remarks on the status of B. latro in the Federated States of Micronesia. J Pacific Sci 66 (4): 509-522. DOI: $10.2984 / 66.4 .8$.

Drew MM, Harzsch S, Stensmyr M, Erland S, Hansson BS. 2010. A review of the biology and ecology of the robber crab, Birgus latro (Linnaeus, 1767) (Anomura: Coenpbitidae). Zoologischer Anzeiger 249: 45-67. DOI: 10.1016/j.jcz.2010.03.001.

Flechter WJ, Brown IW, Fielder DR. 1990. Growth of the coconut crab Birgus latro in Vanuatu. J Exp Mar Biol Ecol 141 (1): 63-78. DOI: 10.1016/0022-0981(90)90158-9.

Fletcher WJ, Brown IW, Fielder DR. 1991. Moulting and growth characteristics. In: Brown IW, Fielder DR (eds). The Coconut Crab: Aspects of the Biology and Ecology of Birgus latro in the Republic of Vanuatu, Vol. 8. Australian Centre for International Agricultural Research, Canberra, Australia.

Gulland JA. 1983. Fish Stock Assessment. A Manual of Basic Method. FAO/Wiley Series, Food and Agriculture, Rome.

Krebs CJ. 1989. Ecological Methodology. Harper Collins Publishers, New York.

Krieger J, Grandy R, Drew MM, Erland S, Stensmyr MC, Harzsch S, Hansson BS. 2012. Giant robber crabs monitored from Space: GPSbased telemetric studies on Christmas Island (Indian Ocean). PLoS One 7 (11): e49809. DOI: 10.1371/journal.pone.0049809.

Nikolsky GV. 1963. The Ecology of Fishes. Academic Press, London.

Oka S, Miyamoto K, Matsuzaki S, Sato T. 2015. Growth of the coconut crab, Birgus latro, at its northernmost range estimated from markrecapture using individual identification based on carapace grooving patterns. J Zoolog Sci 32 (3): 260-265. DOI: 10.2108/zs150008.

Oka S, Miyamoto K, Matsuzaki S. 2016a. Long-term sedentary behavior of coconut crabs in their Northernmost range. Intl J Pure Appl Zool 4 (2): 174-178.

Oka SI, Tomita T, Miyamoto K. 2016b. A mighty claw: Pinching force of the coconut crab, the largest terrestrial crustacean. PLoS ONE 11 (11): e0166108. DOI: 10.1371/journal.pone.0166108.

Pauly D. 1984. Fish population dynamics in tropical water: A manual for use with programmable calculator. ICLARM, Manila, Philippines.

Sato T, Yoseda K, Abe O, Shibuno T, Takada Y, Dan S, Hamasaki K. 2013. Growth of the coconut crab Birgus latro estimated from markrecapture using passive integrated transponder (PIT) tags. J Aquat Biol 19 (2): 143-152. DOI: 10.3354/ab00517.

Sato T, Yoseda K, Abe O, Shibuno T. 2008. Male maturity, number of sperm, and spermatophore size relationships in the coconut crab Birgus latro on Hatoma Island, southern Japan. J Crust Biol 28 (4): 663-668. DOI: 10.1651/07-2966.1

Sato T, Yoseda K. 2013. Reproductive migration of the coconut crab Birgus latro. Plankton Benthos Res 8 (1): 49-54. DOI: 10.3800/pbr.8.49.

Schiller CB, Fielder DR, Brown IW, Obed A. 1991. Reproduction, early life-history and recruitment. In: Brown IW, Fielder DR (eds). The 
Coconut Crab: Aspects of the Biology and Ecology of Birgus latro in the Republic of Vanuatu. ACIAR Monograph, Australia.

Schiller CB. 1988. Spawning and larval recruitment in the coconut crab (Birgus latro) on Christmas Island, Indian Ocean. Consultancy record prepared for the Australian National Parks and Wildlife Service. University of Queensland, Zoology Department, St Lucia, QLD, Australia.

Sparre P, Venema SC. 1999. Introduction of assessment of tropical fish stocks. Book I-Manual (translation edition). Collaboration on food organizations. United Nations with Fisheries Research and Development Centers, Agricultural Research and Development Agencies, Jakarta.
Sulistiono, Affandi R, Supyan. 2013. Study on the potential of small size coconut crabs (Birgus latro) as the basis of domestication in Yoi Island, Central Halmahera. Proceeding of the National Forum Recovery of Fish Resource Conservation IV. KKP-FPIK UNPADMII. KPSI 29. [Indonesian]

Supyan, Sulistiono, Syazili A. 2015. Growth and estimation on the first maturity of the coconut crab gonad (Birgus latro) in Uta Island, North Maluku Province. J Torani Mar Fish Sci 25 (2): 122-133. [Indonesian].

Widodo J, Suadi. 2006. Management of Marine Fishery Resources. Gadjah Mada University Press, Yogyakarta. [Indonesian]. 